\title{
New copper(II) salicylaldimine derivatives for mild oxidation of cyclohexane
}

\author{
ASANDA V BUSA ${ }^{\mathrm{a}, *} \mathbb{D}$, ROGER LALANCETTE $^{\mathrm{b}}, \mathrm{EBBE} \mathrm{NORDLANDER}^{\mathrm{c}}$ and \\ MARTIN ONANI ${ }^{\mathrm{a}}$ \\ ${ }^{a}$ Department of Chemistry, University of the Western Cape, Private Bag X17, Bellville 7535, South Africa \\ ${ }^{\mathrm{b}}$ Department of Chemistry, Rutgers University - Newark, 73 Warren St, Newark, NJ 07102-1811, USA \\ ${ }^{\mathrm{c} C h e m i c a l}$ Physics, Department of Chemistry, Lund University, Box 124, 22100 Lund, Sweden \\ E-mail: monani@uwc.ac.za
}

MS received 15 November 2017; revised 19 March 2018; accepted 27 March 2018; published online 26 May 2018

\begin{abstract}
Two new salicylaldiminato-copper(II) complexes, $\left[\mathrm{Cu}\left(\mathbf{L}^{\mathbf{1}}\right)_{2}\right]$ (1) and $\left[\mathrm{Cu}\left(\mathbf{L}^{\mathbf{2}}\right)_{2}\right]$ (2) (where $\mathbf{H L}^{\mathbf{1}}=$ 4-tert-Butyl-2-[(thiophen-2-ylmethylimino)-methyl]-phenol and $\mathbf{H L}^{2}=2$, 4-Di-tert-butyl-6[(thiophen-2-ylmethylimino)-methyl]-phenol), endowed with a pendant thiophenyl moiety, were synthesized and characterized using standard spectroscopic techniques (FT-IR, UV-Vis, MS) and elemental analysis. Complexes 1 and $\mathbf{2}$ were unequivocally characterized by single crystal X-ray crystallography, which confirmed bidentate bis-chelation of the deprotonated $-\mathbf{L}^{\mathbf{1}}$ and $-\mathbf{L}^{\mathbf{2}}$ ligands to the copper (II) centres via the phenoxo and imine atoms forming square planar complexes. The copper(II)-hydroperoxo derivatives of $\mathbf{1}$ and $\mathbf{2}$ $\left(\left[\left(\mathbf{L}^{\mathbf{1}}\right)_{2} \mathrm{Cu}^{\mathrm{II}}-\mathrm{OOH}\right](\mathbf{3})\right.$ and $\left.\left[\left(\mathbf{L}^{\mathbf{2}}\right)_{2} \mathrm{Cu}^{\mathrm{II}}-\mathrm{OOH}\right](\mathbf{4})\right)$ were also synthesized and the formation of the active intermediate in solution studied. Complexes $\mathbf{1}$ and $\mathbf{2}$ were tested as catalyst precursors in cyclohexane oxidation under mild reaction conditions using hydrogen peroxide $\left(\mathrm{H}_{2} \mathrm{O}_{2}\right)$ as a terminal oxidant, and were found to catalyse oxidation of the substrate with yields comparable to similar mononuclear and even multinuclear copper complexes.
\end{abstract}

Keywords. Copper; oxidation; hydroperoxo complex; cyclohexane.

\section{Introduction}

Salicylaldimines constitute a sub-class of Schiff-base compounds that have been widely studied as ligands to transition metals because such complexes exhibit interesting magnetic, spectral, catalytic and redox properties and may be used as biomimetic models for various biological metal sites. ${ }^{1-3}$ Copper(II) complex, chelated by a salophen ligand that is endowed with different electron donating and withdrawing groups, has been investigated as a model in the oxidation of primary alcohols. ${ }^{4}$ The inclusion of sterically demanding substituents such as tert-butyl groups on the salicylaldimine moiety alters the ensuing electronic and chemical properties of the metal complexes. ${ }^{5}$ The literature reveals a limited number of copper(II) complexes with sterically demanding tert-butyl substituents on the salicylaldimine ligands. ${ }^{6-8}$ Also, only a limited number of mono-,${ }^{9-13}$ di-,${ }^{14-16}$ and multinuclear ${ }^{17-20}$ copper(II) complexes have been reported to catalytically functionalize $\mathrm{C}-\mathrm{H}$ bond of alkanes under mild reaction conditions. Some salicylaldiminato-copper(II) complexes have been shown to catalyse a range of chemical reactions such as selective aerobic oxidation of primary alcohols to corresponding aldehydes. ${ }^{21-24}$ It has also been demonstrated that endowing the chelating phenolate ligands with bulky tert-butyl substituents at the ortho- and para-position imparts stability to the ensuing phenoxyl radical complexes. ${ }^{5,25}$

Notably, some copper(II) complexes have been employed as functional models of the copper enzyme Galactose Oxidase (GO) in the oxidative transformation of primary alcohols to corresponding aldehydes with a consequent reduction of dioxygen to a peroxide, i.e. hydrogen peroxide. ${ }^{26,27}$ This catalytic transformation involving enzyme models has been suggested to proceed

\footnotetext{
*For correspondence

Electronic supplementary material: The online version of this article (https://doi.org/10.1007/s12039-018-1455-y) contains supplementary material, which is available to authorized users.
} 
<smiles>[R]c1cc(C(C)(C)C)cc(/C=N/Cc2cccs2)c1O</smiles>

$\mathrm{R}_{1}=\mathrm{H}, \mathbf{H L}^{1}$

$\mathrm{R}_{1}=$ tert -But, $\mathbf{H L}^{2}$

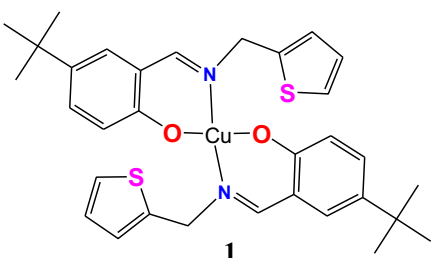

(i)

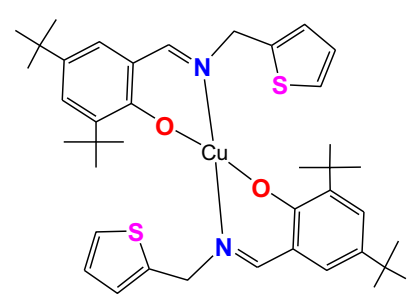

2 (ii)
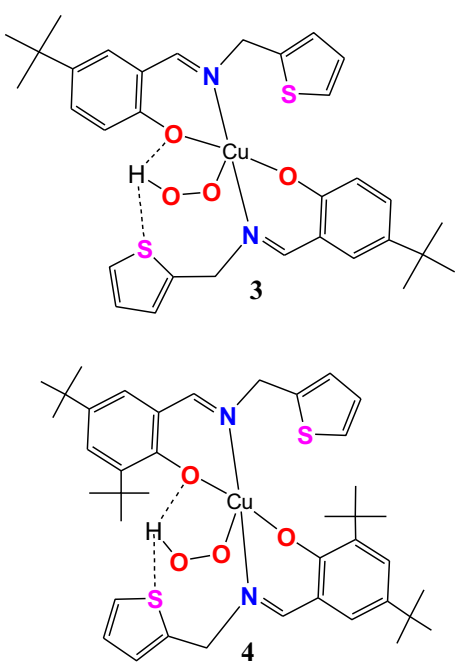

Reagents and reaction conditions: (i) $\mathrm{CuCl}_{2} \cdot 2 \mathrm{H}_{2} \mathrm{O}, \mathrm{MeOH}, \mathrm{Et}_{3} \mathrm{~N}, 12 \mathrm{~h}, \mathrm{rt}$

(ii) $\mathrm{CH}_{3} \mathrm{CN}: \mathrm{MeOH}(1: 1), \mathrm{H}_{2} \mathrm{O}_{2}: \mathrm{Et}_{3} \mathrm{~N}$ (10:2), rt

Scheme 1. Synthesis of complexes $\mathbf{1}$ and $\mathbf{2}$ and the copper(II)-hydroperoxoc intermediates, 3 and 4.

via the formation of active mononuclear $\mathrm{Cu}-\mathrm{O}_{2}{ }^{28-31}$ and copper(II)-hydroperoxo ( $\left.\mathrm{Cu}^{\mathrm{II}}-\mathrm{OOH}\right)$ intermediates. ${ }^{32-35}$ Recently, a mononuclear salicylaldiminato-copper(II) complex coordinated by $\mathrm{N}_{2} \mathrm{O}_{2}$-donor atoms was found to be effective in the catalytic oxidation of aromatic hydrocarbons. This complex effects the oxidation of hydrocarbons via the formation of a catalytically active copper(II)-hydroperoxo intermediate. It was shown that the presence of a pendant pyrazolyl arm stabilizes the copper(II)-hydroperoxo intermediate $[\mathrm{LCu}-\mathrm{OOH}]^{-}$via formation of hydrogen bonding. ${ }^{9,13}$ Such hydrogen bond interaction has been shown to be vital for the stabilization of the rather unstable intermediate $[\mathrm{LCu}(\mathrm{II})$ $\mathrm{OOH}] .{ }^{34 \mathrm{a}}$

We wished to expand the scope of sterically demanding tert-butyl salicylaldiminato-copper complexes by preparing the bis- $\mathrm{N}_{2} \mathrm{O}_{2}$-chelated salicylaldiminatocopper(II) complexes $\left[\mathrm{Cu}\left(\mathbf{L}^{\mathbf{1}}\right)_{2}\right](\mathbf{1})$ and $\left[\mathrm{Cu}\left(\mathbf{L}^{\mathbf{2}}\right)_{2}\right](\mathbf{2})$ that possess a pendant hemilabile thiophenyl moiety (Scheme 1). The purpose of introducing a pendant thiophenyl arm is to stabilize a potential [ $\mathrm{LCu}(\mathrm{II})$ $\mathrm{OOH}]$ intermediate in solution via hydrogen bonding between the thiophene and hydroperoxo moieties. The copper(II) complexes were evaluated as catalyst precursors in the mild oxidation of cyclohexane by $\mathrm{H}_{2} \mathrm{O}_{2}$. The formation of catalytically active copper(II)hydroperoxo intermediates in solution was also investigated. We propose a catalytic cycle for oxidation of cyclohexane by $\mathrm{H}_{2} \mathrm{O}_{2}$ effected by complexes $\mathbf{1}$ and 2.

\section{Experimental}

\subsection{Materials and Methods}

All experimental manipulations were carefully carried out under inert nitrogen atmosphere using standard dual vacuum/nitrogen lines and Schlenk techniques. All commercial chemicals were purchased from Sigma-Aldrich and were used as received. The solvents were dried and purified by heating at reflux under nitrogen in the presence of a suitable drying agent; methanol was dried over magnesium. Acetonitrile was dried over 3 Åmolecular sieves. Reaction progress and product mixtures were monitored by IR spectroscopy. Anhydrous magnesium sulphate $\left(\mathrm{MgSO}_{4}\right)$ was used for drying. NMR spectra were recorded on Varian Inova $500 \mathrm{MHz}$ (Lund University, Sweden) or Bruker Avance III HD $400 \mathrm{MHz}$ (University of the Western Cape, South Africa) spectrometers using the solvent resonance as an internal standard for ${ }^{1} \mathrm{H}$ NMR and ${ }^{13} \mathrm{C}$ NMR shifts. Infrared spectra were recorded on a Nicolet Avatar 360 FT-IR spectrometer (Lund University, Sweden). The GC analysis were carried out on an Agilent 7890 gas chromatograph, GC Column: Agilent $19091 \mathrm{~J}-413$; $325^{\circ} \mathrm{C}: 30 \mathrm{mX} 320 \mu \mathrm{mX0} 0.25 \mu \mathrm{m}, 5 \%$ phenyl methyl Siloxan HP5-column.

\subsection{Synthesis of the salicylaldimine ligand precursors $\boldsymbol{H L}^{1}$ and $\boldsymbol{H L}^{2}$}

A solution of $3-^{t} B u$-salicylaldehyde $(0.314 \mathrm{~g}, 2 \mathrm{mmol})$ in dry methanol $(10 \mathrm{~mL})$ was stirred at room temperature and a solution of 2-thiophenemethylamine $(0.199 \mathrm{~g}, 2 \mathrm{mmol})$ in dry methanol $(10 \mathrm{~mL})$ was added to the solution, dropwise. The 
colour of the solution changed immediately to bright yellow and a yellow precipitate formed. The reaction was monitored by thin layer chromatography (TLC) and was allowed to continue at room temperature for $12 \mathrm{~h}$. The precipitate was collected and washed with cold methanol and hexane. The solids were dried over $\mathrm{CaCl}_{2}$ to obtain yellow crystalline solids after $24 \mathrm{~h} . \mathrm{HL}^{\mathbf{1}}$ : IR data $\left(\mathrm{KBr}, \nu / \mathrm{cm}^{-1}\right)$ : $2924\left(\nu_{\mathrm{CO}-\mathrm{H}}\right)$, $1613\left(\nu_{\mathrm{C}=\mathrm{N}}\right), 1446\left(\nu_{\mathrm{C}=\mathrm{C}}\right) .{ }^{1} \mathrm{H}$ NMR data $\left(\mathrm{CDCl}_{3}, \mathrm{ppm}\right)$ : $12.99(\mathrm{~s}, 1 \mathrm{H}), 8.42(\mathrm{~s}, 1 \mathrm{H}), 7.37-7.39(\mathrm{dd}, J=5.09 \mathrm{~Hz}, 2 \mathrm{H})$, $7.24-7.27(\mathrm{dd}, J=5.08 \mathrm{~Hz}, 2 \mathrm{H}), 7.02-6.97(\mathrm{dd}, J=$ $5.10 \mathrm{~Hz}, 2 \mathrm{H}), 6.931$ (d, $J=5.11 \mathrm{~Hz}, 1 \mathrm{H}), 4.97(\mathrm{~s}, 2 \mathrm{H}), 1.25$ $(\mathrm{s}, 3 \mathrm{H}) .{ }^{13} \mathrm{C} \mathrm{NMR}\left(\mathrm{CDCl}_{3}, \mathrm{ppm}\right): 161.6(\mathrm{C}=\mathrm{N}), 158.2(\mathrm{C}-$ $\mathrm{OH}), 142.1,140.3,127.3,126.9,126.2,125.6,119.1,55.3$, 41.4, 33.1, 32.2. Anal. Calc. For $\mathrm{C}_{16} \mathrm{H}_{19} \mathrm{NOS}$ : C, 70.29; H, $7.00 ;$ N, 5.12\%. Found: C, 70.55; H, 7.08; N, 5.42\%. ESI-MS, $m / z: 273\{[\mathrm{M}]+\mathrm{H}\}$

The ligand $\mathbf{H L}^{2}$ was obtained by following the abovementioned procedure for the synthesis of $\mathbf{H L}^{\mathbf{1}}$. HL $\mathbf{H L}^{\mathbf{2}}$ : IR data $\left(\mathrm{KBr}, \nu / \mathrm{cm}^{-1}\right) 2980\left(\nu_{\mathrm{CO}-\mathrm{H}}\right), 1637 \mathrm{~s}\left(\nu_{\mathrm{C}=\mathrm{N}}\right), 1505\left(\nu_{\mathrm{C}=\mathrm{C}}\right)$. ${ }^{1} \mathrm{H}$ NMR data $\left(\mathrm{CDCl}_{3}, \mathrm{ppm}\right): 13.51(\mathrm{~s}, 1 \mathrm{H}), 8.42(\mathrm{~s}, 1 \mathrm{H})$, $7.41(\mathrm{dd}, J=5.09 \mathrm{~Hz}, 1 \mathrm{H}), 7.26(\mathrm{dd}, J=5.08 \mathrm{~Hz}, 1 \mathrm{H})$, $7.15(\mathrm{~d}, J=5.10 \mathrm{~Hz}, 1 \mathrm{H}), 7.01(\mathrm{dd}, J=5.11 \mathrm{~Hz}, 1 \mathrm{H}), 4.98$ (s, 2H), 1.45 (s, 3H), 1.34 (s, 3H). ${ }^{13} \mathrm{C} \mathrm{NMR}\left(\mathrm{CDCl}_{3}, \mathrm{ppm}\right)$ : $166.2(\mathrm{C}=\mathrm{N}), 159.9(\mathrm{C}-\mathrm{OH}), 155.2,141.1,139.3,137.1$, 126.8, 126.6, 126.2, 123.3, 55.3, 42.1, 34.2, 33.9, 30.8. Anal. Calc. For $\mathrm{C}_{20} \mathrm{H}_{27} \mathrm{NOS}$ : C, 72.90; H, 8.26; N, 4.25\%. Found: C, 72.13; H, 8.31; N, 4.55\%. ESI-MS, $m / z: 330.47\{[\mathrm{M}]+\mathrm{H}\}$

\subsection{Synthesis of bis[N-(thiophenyl)-3-tert-butyl salicylaldiminato] (1) and bis[N-(phenyl)-3,5 -di-tert-butyl salicylaldiminato] (2) copper(II) complexes}

A methanol $(10 \mathrm{~mL})$ solution of the ligand $\mathbf{H L}^{\mathbf{1}}(0.04 \mathrm{mmol})$ was stirred at room temperature for $30 \mathrm{~min}$ in the presence of triethylamine $\left(\mathrm{Et}_{3} \mathrm{~N}, 0.04 \mathrm{mmol}\right)$ in order to deprotonate $\mathbf{H L}^{\mathbf{1}}$. A methanol $(10 \mathrm{~mL})$ solution of $\mathrm{CuCl}_{2} \cdot 2 \mathrm{H}_{2} \mathrm{O}(0.02 \mathrm{mmol})$ was subsequently added dropwise into the ligand solution and the reaction mixture was stirred at room temperature for $12 \mathrm{~h}$. The solvent volume was then reduced under vacuum to $\sim 3 \mathrm{~mL}$ and the complex was precipitated with cold diethyl ether. The precipitate was filtered and washed with copious amount of diethyl ether and kept under reduced pressure for several hours.

1: IR data $\left(\mathrm{KBr}, \nu / \mathrm{cm}^{-1}\right)$ 2945-2855 $\left(\nu_{\mathrm{C}-\mathrm{H}}\right.$ 3-tert-butyl group), $1608\left(v_{\mathrm{C}=\mathrm{N}}\right), 1238\left(v_{\mathrm{C}-\mathrm{O}}\right)$. Anal. Calc. $\mathrm{C}_{32} \mathrm{H}_{36} \mathrm{CuN}_{2}$ $\mathrm{O}_{2} \mathrm{~S}_{2} \mathrm{C}, 63.18 ; \mathrm{H}, 5.96 ; \mathrm{N}, 4.61 \%$. Found: C, 62.82; H, $5.43 ; \mathrm{N}, 4.08 \%$. ESI-MS ${ }^{+}, m / z: 608.17\left\{\left[\mathrm{Cu}(\mathrm{L})_{2}\right]+\mathrm{H}^{+}\right\}$and $630.15\left\{\left[\mathrm{Cu}(\mathrm{L})_{2}\right]+\mathrm{Na}^{+}\right\}$

Complex $\mathbf{2}$ was synthesized following the same methodology reported above for $\mathbf{1}$.

2: IR data $\left(\mathrm{KBr}, \nu / \mathrm{cm}^{-1}\right)$ 2960-2860 ( $\nu_{\mathrm{C}-\mathrm{H}}, 3,5$-tertbutyl groups), $1605\left(\nu_{\mathrm{C}=\mathrm{N}}\right), 1250\left(\nu_{\mathrm{C}-\mathrm{O}}\right)$. Anal. Calc. $\mathrm{C}_{40} \mathrm{H}_{52} \mathrm{CuN}_{2} \mathrm{O}_{2} \mathrm{~S}_{2} \mathrm{C}$, 66.68; H, 7.27; N, 3.89\%. Found: C, 66.32; H, 7.44; N, 3.72\%. ESI-MS ${ }^{+}, m / z: 720.29\left\{\left[\mathrm{Cu}\left(\mathbf{L}^{2}\right)_{2}\right]\right.$ $\left.+\mathrm{H}^{+}\right\}$and $742.28\left\{\left[\mathrm{Cu}\left(\mathbf{L}^{2}\right)_{2}\right]+\mathrm{Na}^{+}\right\}$

\subsection{Structure determination by single-crystal $X$-ray Crystallography}

Single-crystal X-ray diffraction data were collected on a Bruker KAPPA APEX II DUO diffractometer that employs a graphite-monochromated Mo-K $\alpha$ radiation $(\lambda=0.71073 \AA)$. The operational temperature for data collection was 173(2) $\mathrm{K}$. Temperature regulations was carried out with an Oxford Cryostream cooling system (Oxford Cryostat). Cell refinement and data reduction were performed using the program SAINT. ${ }^{45}$ The data were scaled and absorption correction performed using SADABS. ${ }^{45 a}$ The structures were solved by direct methods using SHELXS-97 ${ }^{45 b}$ and refined by fullmatrix least-squares methods based on $F^{2}$ using SHELXL$2014^{45 c}$ and using the graphics interface program X-Seed. ${ }^{45 d}$ All non-hydrogen atoms were refined anisotropically. All the aromatic hydrogen atoms were placed in idealised positions and refined in riding models with $\mathrm{U}_{\text {iso }}$ assigned 1.2 or 1.5 times $\mathrm{U}_{\mathrm{eq}}$ of their parent atoms and the bond distances were constrained from 0.95 to $0.99 \AA$. The structures were refined to R-factors of 0.0394 for $\mathbf{1}$ and 0.0437 for 2 . The parameters for crystal data collection and structure refinements, and the bond lengths and angles are contained in Tables 1 and 2, respectively.

\subsection{Catalysis}

The catalytic activity studies were carried out following reported methodologies. ${ }^{18}$ The catalytic mixtures for complex 1 and $\mathbf{2}$ were prepared as follows: To a solution of complex $1(4.10 \mathrm{mg}, 6.75 \mu \mathrm{mol})$ dissolved in $5 \mathrm{~mL}$, dry MeCN, $\mathrm{H}_{2} \mathrm{O}_{2}(82.6 \mu \mathrm{L}, 2.70 \mathrm{mmol})$ and $\mathrm{HNO}_{3}(3.06 \mu \mathrm{L}, 0.06 \mathrm{mmol})$ were added and stirred for a short time. Cyclohexane $(8.0 \mu \mathrm{L}, 0.17 \mathrm{mmol})$ was subsequently added and the reaction was allowed to stir for $36 \mathrm{~h}$ at room temperature. Aliquots $(100 \mu \mathrm{L})$ from the reaction mixture were withdrawn at specific time intervals during the reaction time. Cycloheptanone ( $9 \mu \mathrm{L}$, internal standard) and $90 \mu \mathrm{L}$ of ether were added to the aliquots to extract the substrate and product. An appropriate volume was sampled from the mixture and injected into a GC. Retention times from the catalytic mixture were compared with commercial standards.

\section{Results and Discussion}

The proligands $\mathbf{H L}^{\mathbf{1}}$ and $\mathbf{H L}^{\mathbf{2}}$ (Scheme 1) were prepared according to literature procedures. ${ }^{36-39}$ The complexes $\left[\mathrm{Cu}\left(\mathbf{L}^{\mathbf{1}}\right)_{2}\right]$ (1) and $\left[\mathrm{Cu}\left(\mathbf{L}^{2}\right)_{2}\right]$ (2) were prepared in methanol in the presence of $\mathrm{Et}_{3} \mathrm{~N}$ (Scheme 1) and isolated after $12 \mathrm{~h}$ as brown solids in excellent yields of 90 (1) and $87 \%$ (2). Coordination of the deprotonated form of the ligands, $-\mathbf{L}^{\mathbf{1}}$ and $-\mathbf{L}^{\mathbf{2}}$, was monitored by thin layer chromatography and confirmed by IR spectroscopy. Disappearance of the hydroxyl $(\mathrm{O}-\mathrm{H})$ stretching frequency present in the ligands and the hypsochromic 
Table 1. Data collection and selected parameters for complexes $\mathbf{1}$ and 2.

\begin{tabular}{|c|c|c|}
\hline & 1 & 2 \\
\hline Formula & $\mathrm{C}_{32} \mathrm{H}_{36} \mathrm{CuN}_{2} \mathrm{O}_{2} \mathrm{~S}_{2}$ & $\mathrm{C}_{32} \mathrm{H}_{36} \mathrm{CuN}_{2} \mathrm{O}_{2} \mathrm{~S}_{2}$ \\
\hline Formula weight & 608.30 & 720.51 \\
\hline$T, K$ & 100 & 173 \\
\hline Crystal system & Monoclinic & Monoclinic \\
\hline Space group & $P 21 / c$ & $P 21 / c$ \\
\hline $\mathrm{a} / \AA$ & $12.198(2)$ & $16.1516(18)$ \\
\hline $\mathrm{b} / \AA$ & $5.812(2)$ & $13.2501(14)$ \\
\hline $\mathrm{c} / \AA$ & $20.371(4)$ & $18.388(2)$ \\
\hline$\alpha / \circ$ & 90.0 & 90.0 \\
\hline$\beta / \circ$ & $95.01(3)$ & $97.335(2)$ \\
\hline$\gamma / 0$ & 90.0 & 90.0 \\
\hline$U / \AA^{3}$ & $1438.7(7)$ & $3903.0(7)$ \\
\hline$Z$ & 2 & 4 \\
\hline$D / \mathrm{g} . \mathrm{cm}^{-3}$ & 1.404 & 1.226 \\
\hline$\mu / \mathrm{mm}^{-1}$ & 2.678 & 0.701 \\
\hline$F(000)$ & 638.0 & 1532.0 \\
\hline No. of measured reflections & 2511 & 9741 \\
\hline No. of observed reflections & 0.030 & 0.074 \\
\hline Parameter refined & 182 & 467 \\
\hline No of reflections $[\mathrm{I}>2 \sigma(\mathrm{I})]$ & 2372 & 7290 \\
\hline Goodness of fit, $S$ & 1.146 & 1.026 \\
\hline $\mathrm{R}_{1}, \mathrm{wR}_{2}$ (all data) & $0.0394,0.1137$ & $0.0441,0.1220$ \\
\hline
\end{tabular}

Table 2. Selected bond lengths $[\AA]$ and angles $\left[^{\circ}\right]$ for complexes $\mathbf{1}$ and $\mathbf{2}$.

\begin{tabular}{|c|c|c|}
\hline \multicolumn{3}{|c|}{ Interatomic distances } \\
\hline & 1 & 2 \\
\hline $\mathrm{Cu}-\mathrm{O}(1)$ & 1.893 & $1.917(2)$ \\
\hline $\mathrm{Cu}-\mathrm{O}(2)$ & 1.893 & $1.922(2)$ \\
\hline $\mathrm{Cu}-\mathrm{N}(1)$ & 2.001 & $1.959(2)$ \\
\hline $\mathrm{Cu}-\mathrm{N}(2)$ & 2.001 & $1.966(2)$ \\
\hline $\mathrm{N}(1)-\mathrm{C}(11)(\mathbf{1}) / \mathrm{N}(1)-\mathrm{C}(6)(2)$ & $1.290(3)$ & $1.294(3)$ \\
\hline $\mathrm{N}(1)-\mathrm{C}(11)(\mathbf{1}) / \mathrm{N}(1)-\mathrm{C}(26)(2)$ & $1.290(3)$ & $1.292(3)$ \\
\hline \multicolumn{3}{|l|}{ Angles } \\
\hline $\mathrm{O}(1)-\mathrm{Cu}-\mathrm{O}(1)(\mathbf{1}) / \mathrm{O}(1)-\mathrm{Cu}-\mathrm{O}(2)(\mathbf{2})$ & 180.00 & $159.63(7)$ \\
\hline $\mathrm{O}(1)-\mathrm{Cu}-\mathrm{N}(1)$ & 91.94 & $91.64(7)$ \\
\hline $\mathrm{O}(1)-\mathrm{Cu}-\mathrm{N}(2)$ & 88.06 & $90.67(7)$ \\
\hline $\mathrm{O}(2)-\mathrm{Cu}-\mathrm{N}(1)$ & 91.94 & $91.82(7)$ \\
\hline $\mathrm{O}(2)-\mathrm{Cu}-\mathrm{N}(2)$ & 88.06 & $92.22(7)$ \\
\hline $\mathrm{N}-\mathrm{Cu}-\mathrm{N}$ & 180.00 & $161.95(8)$ \\
\hline
\end{tabular}

shifts of the azomethine $(\mathrm{C}=\mathrm{N})$ moiety from $1620 \mathrm{~cm}^{-1}$ (for the free ligands) to 1608 (1) and $1605(2) \mathrm{cm}^{-1}$ for the complexes confirmed participation of the $\mathrm{N}, \mathrm{O}$-donor atoms in the coordination. Complexes $\mathbf{1}$ and $\mathbf{2}$ were confirmed to be bis-chelated by $-\mathbf{L}^{1}$ and $-\mathbf{L}^{2}$, respectively, by ESI-MS, elemental analysis and X-ray crystallography (vide infra).
The UV-Vis spectra of complexes $\mathbf{1}$ and $\mathbf{2}$ exhibited bands in the region $280-640 \mathrm{~nm}$. The bands that appeared at $282 \mathrm{~nm}$ were assigned to $\pi-\pi *$ transitions while the band at $328 \mathrm{~nm}$ was assigned to $\mathrm{n}-\pi^{*}$ transitions. The band at $630 \mathrm{~nm}$ was attributed to a metal to ligand charge transfer (MLCT) between the $\mathrm{Cu}$ (II) centre and the non-bonding orbital of the azomethine $(\mathrm{C}=\mathrm{N})$ moiety. Similar observations are reported in the literature for salicyaldiminato- $\mathrm{Cu}$ (II) complexes, ${ }^{9,13}$ suggesting formation of a distorted square planar geometry for complexes $\mathbf{1}$ and $\mathbf{2}$. Formation of $\mathbf{1}$ and $\mathbf{2}$ was further confirmed by high resolution ESI-MS ${ }^{+}$. Appearance of molecular ion peaks at 608.8378 (1) and 720.9918 (2), respectively, confirmed the presence of the $\left[\mathrm{Cu}\left(\mathbf{L}^{\mathbf{1}} / \mathbf{L}^{\mathbf{2}}\right)_{2}+\mathrm{H}^{+}\right]$parent ions and the appearance of peaks at 630.7742 (1) and $742.9822(\mathbf{2})$ were assigned to the $\left[\mathrm{Cu}\left(\mathbf{L}^{\mathbf{1}} / \mathbf{L}^{2}\right)_{2}+\mathrm{Na}^{+}\right]$ions.

Preparation of intermediates (L) $\mathrm{Cu}(\mathrm{II})-\mathrm{OOH}$ from complex $\mathbf{1}$ and 2, respectively, is depicted in Scheme 1. Formation of $[(\mathbf{L}) \mathrm{Cu}(\mathrm{II})-\mathrm{HOOH}]$ species $\mathbf{3}$ and $\mathbf{4}$, respectively, in solution was confirmed by UV-Vis (Figure 1) and high resolution ESI-MS ${ }^{+}$(SI, Figure S6 in Supplementary Information). In the UV-Vis spectra of $\mathbf{3}$ and $\mathbf{4}$, new characteristic bands at 382 and $580 \mathrm{~nm}$, respectively, were observed. The band at $382 \mathrm{~nm}$ was assigned to the $\mathrm{HOO}^{-} \rightarrow \mathrm{Cu}$ (II) ligandto-metal charge-transfer transition (LMCT) while the 
band at $580 \mathrm{~nm}$ was attributed to $d$ - $d$ transitions of the $\mathrm{Cu}$ (II) centre. These observations were in accordance with $\mathrm{Cu}(\mathrm{II})-\mathrm{OOR}$ complexes reported in the literature and indicative of the formation of a square-pyramidal geometry in solution, ${ }^{40-43}$ and provided strong evidence for interaction of the aqueous $\mathrm{H}_{2} \mathrm{O}_{2}$ with the $\mathrm{Cu}$ (II) centre. The ESI-MS ${ }^{+}$spectra displayed ion peaks at $m / z 608\left[(\mathbf{L})_{2} \mathrm{Cu}\right]^{++}, 642\left(\left[(\mathbf{L})_{2} \mathrm{Cu}-\mathrm{HOOH}\right]^{++}\right), 665$ $\left(\left[(\mathbf{L})_{2} \mathrm{Cu}-\mathrm{OOH}\right]+\mathrm{Na}^{+}\right]$and $681\left[(\mathbf{L})_{2} \mathrm{Cu}-\mathrm{HOOH}+\right.$ $\mathrm{K}^{+}$] for 3. The corresponding ion peaks for 4 were observed at $\mathrm{m} / \mathrm{z} 720\left[(\mathbf{L})_{2} \mathrm{Cu}\right]^{+}, 754\left(\left[(\mathbf{L})_{2} \mathrm{Cu}-\right.\right.$ $\left.\mathrm{HOOH}]^{+}\right), 777\left(\left[(\mathbf{L})_{2} \mathrm{Cu}-\mathrm{OOH}\right]+\mathrm{Na}^{+}\right]$and $793\left[(\mathbf{L})_{2}\right.$ $\mathrm{Cu}-\mathrm{HOOH}+\mathrm{K}^{+}$], indicative of the formation of the $\left(\mathbf{L}^{\mathbf{1}} / \mathbf{L}^{2}\right)_{2} \mathrm{Cu}(\mathrm{II})-\mathrm{HOOH}$ species in solution.

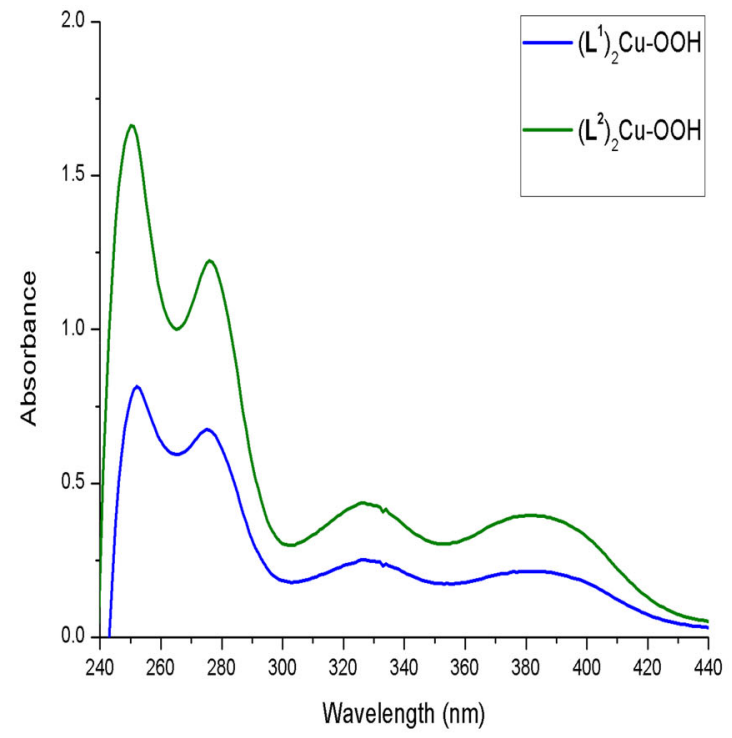

The X-ray crystal structures of complexes $\mathbf{1}$ and $\mathbf{2}$ confirmed bis-chelation of $-\mathbf{L}^{1}$ and $-\mathbf{L}^{2}$ to the $\mathrm{Cu}(\mathrm{II})$ centre, respectively, through the $\mathrm{N}_{2} \mathrm{O}_{2}$ donor atoms in a head-to-head fashion with the two salicylaldiminato oxygens trans to each other. The molecular structures of complexes $\mathbf{1}$ and $\mathbf{2}$ are depicted in Figure 2. The $\mathrm{C}-\mathrm{N}$ and $\mathrm{C}-\mathrm{O}$ bond distances for $\mathbf{1}(1.893 \AA)$ and $2(1.917(2) \AA)$ were within reported limits for similar compounds ${ }^{9,13}$ while the dihedral angles defined by $\mathrm{O}(1)-\mathrm{Cu}(1)-\mathrm{O}(1) / \mathrm{N}(1)-\mathrm{Cu}(1)-\mathrm{N}(1)$ and $\mathrm{O}(1)-\mathrm{Cu}(1)-$ $\mathrm{N}(1)$ for 1 were $180.0^{\circ}$ and $91.94^{\circ}$, respectively, the same dihedral angles for 2 were $159.63(7)^{\circ}$ and $161.95(8)^{\circ}$. The dihedral angles for $\mathbf{2}$ were observed to deviate from the classical square planar geometry. The steric demand

Figure 1. Electronic spectra of $\left(\mathbf{L}^{\mathbf{1}}\right)_{2} \mathrm{Cu}(\mathrm{II})-\mathrm{OOH}(\mathbf{3}, 0.5 \mathrm{mM})$ and $\left.\left(\mathbf{L}^{\mathbf{2}}\right)_{\mathbf{2}} \mathrm{Cu}(\mathrm{II})-\mathrm{OOH}\right](\mathbf{4}, 1 \mathrm{mM})$ hydroperoxo species in MeCN:MeOH (1:1).
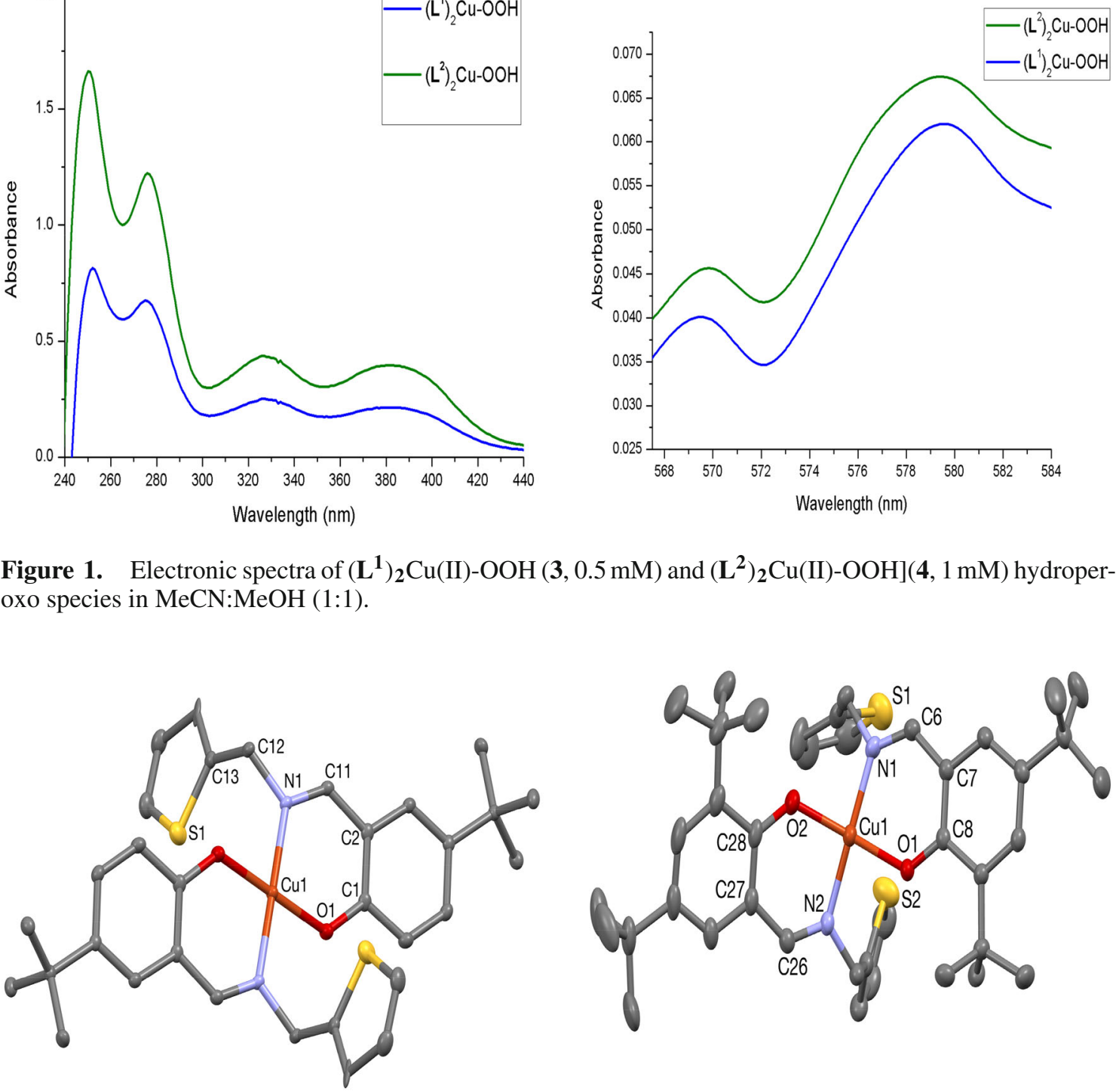

Figure 2. X-ray crystal structure of $\mathbf{1}$ (left) and $\mathbf{2}$ (right) at 30\% probability level with hydrogen atoms omitted for clarity. The partial occupancy of the carbon site by the sulfur atom of the thiophene moiety in $\mathbf{1}$ is shown. 
<smiles>C1CCCCC1</smiles>

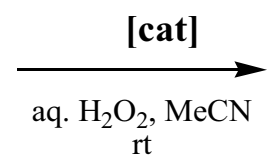

[cat $]=$

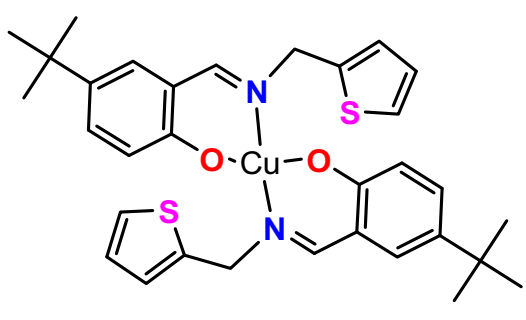

1<smiles>O=C1CCCCC1</smiles>

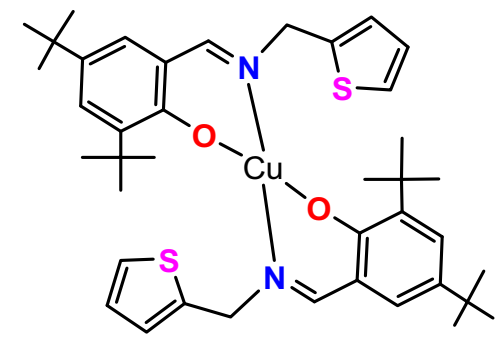

2

Scheme 2. General depiction of peroxidative catalytic oxidation of cyclohexane.

around the chelating environment, with the tert-butyl susbstituents in 6-positions preventing coplanarity, is a likely reason for the observed deviation. Complex 1 displays a static/flip disorder of about $180^{\circ}$ in the thiophenyl moiety with a partial occupancy of the carbon site by the sulfur atom. ${ }^{46 a}$ Complex 2 displays rotational disorder around the methyl carbons of the tertbutyl moiety, with site occupancy factor of 0.608 , i.e., $61 \%$ for the dominant population and 0.39 i.e., $39 \%$ for the minor population. These observations have been reported for similar compounds and only the dominant site occupancy is shown in the X-ray crystal structure of 2 (Figure 2). ${ }^{46 b, c}$

Complexes $\mathbf{1}$ and $\mathbf{2}$ were evaluated as catalyst precursors in the oxidation of cyclohexane, employing $30 \%$ hydrogen peroxide as an oxidant in an acidic $\left(\mathrm{HNO}_{3}\right)$ acetonitrile solution (Scheme 2). The $\mathrm{n}\left(\mathrm{NHO}_{3}\right)$ / $\mathrm{n}$ (catalyst) and $\mathrm{n}\left(\mathrm{H}_{2} \mathrm{O}_{2}\right) / \mathrm{n}$ (catalyst) ratios were chosen to be 10 and 400, respectively. These parameters have been shown to stabilize the catalytic centre and to predominantly favour formation of alcohols. ${ }^{17,18}$ Complexes 1 and $\mathbf{2}$ were observed to mildly oxidise cyclohexane within the first $3 \mathrm{~h}$ with $6.22 \%$ (1) and $7.98 \%$ (2) conversions to cyclohexanol and $4.12 \%$ (1) and $3.1 \%$ (2) conversion to cyclohexanone. Both complexes $\mathbf{1}$ and $\mathbf{2}$ favoured the formation of cyclohexanol throughout the catalytic cycle, although an increase in the percentage yield of cyclohexanone was observed with time. The observed increased concentration of cyclohexanone in the solution was attributed to the in situ oxidation of cyclohexanol and the possible contribution from other byproducts (acids) present in solution in small quantities. ${ }^{11}$ The reaction profile for alcohol selectivity was observed to increase after $12 \mathrm{~h}$ for both reactions catalysed by $\mathbf{1}$ and $\mathbf{2}$, individually, while the $\%$ yield of cyclohexanone increased slightly. The highest cyclohexane conversions were reached at $36 \mathrm{~h}$ with yields of $18.10 \%$ (1) and $19.54 \%$ (2) of cyclohexanol formation, leading us to conclude that the increase in the steric hindrance around the chelating N,O-donor atoms by introducing an additional tert-butyl in ligand $\mathbf{H L}^{2}$ did not impart significant influence on the catalytic activity of complex $\mathbf{2}$ as originally envisioned.

Although complexes $\mathbf{1}$ and $\mathbf{2}$ exhibited lower catalytic activities than some other copper(II) complexes reported in the literature, ${ }^{17}$ these preliminary catalytic results are comparable to some of the reported mono-, di- and multinuclear copper(II) complexes. ${ }^{11,17,18,47}$ These complexes exhibited higher catalytic activity compared to simple copper(II) salts under the same reaction conditions. ${ }^{17,47}$ The oxidation of stable alkanes such as cyclohexane (C-H bond dissociation energy $=$ $99 \mathrm{kcal} / \mathrm{mol}$ ) usually requires harsh reaction conditions that are not applied here (Figure 3; Table 3).

On the basis of previous studies, ${ }^{9,13,44}$ and in accordance with the detected formation of the copper(II)hydroperoxo $\left(\mathrm{LCu}^{\mathrm{II}}-\mathrm{OOH}\right)$ species in solution (vide supra), we propose that the catalytic cycle in the oxidation of cyclohexane by $\mathrm{H}_{2} \mathrm{O}_{2}$ using complex 1 and 2 , respectively, proceeds via formation of $\mathrm{HO}$ and 

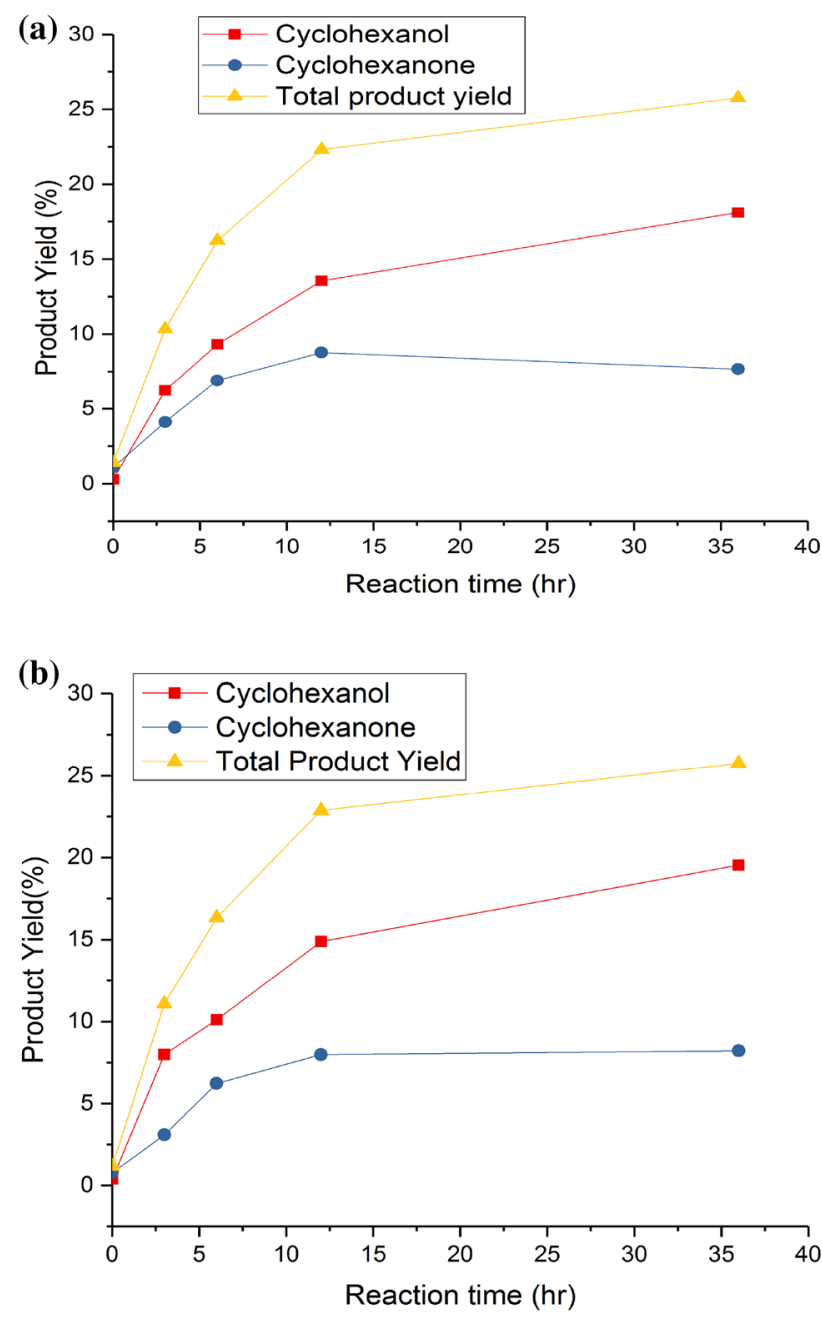

Figure 3. Conversion of cyclohexane as a function of time catalysed by $\mathbf{1}$ (a) and $\mathbf{2}$ (b).
HOO radicals as reported for similar salicylaldiminatocopper(II) complexes under similar reaction conditions (Scheme 3). This proposal is supported by Density Functional Theory calculations. ${ }^{9,13,44}$ The formation of the potent $\mathrm{HO}$ radical in solution has been shown to be encouraged by the metal-assisted degradation of the oxidant, $\mathrm{H}_{2} \mathrm{O}_{2}$, and to be responsible for the proton abstraction from the substrate (cyclohexane). ${ }^{9,13}$ As a result, proton abstraction from the substrate ensues the formation of the alkyl radical ( $\mathrm{R} \cdot$ ). The in situ reaction of the alkyl radical with $\mathrm{LCu}(\mathrm{II})-\mathrm{OOH}$ generates $\mathrm{ROOH}$ that is subsequently cleaved to form oxyl (RO-) and the peroxyl (ROO.) radicals, respectively. These radicals facilitate formation of the oxidation products via proton abstraction from the substrate. Based on the detection of the (L) $\mathrm{Cu}(\mathrm{II})-\mathrm{OOH}$ species in solution by UV-Vis and HR-ESI-MS analysis (vide supra), we propose that the catalytic cycle for the formation of oxidation products (alcohol and ketone) to proceed via generation of the alkyl radicals that subsequently abstract a proton from the substrate.

\section{Conclusions}

In conclusion, complexes $\mathbf{1}$ and $\mathbf{2}$ have been successfully synthesized and crystallographically characterized to be bis-chelated by the tert-butylated phenolate. They both react with aqueous $\mathrm{H}_{2} \mathrm{O}_{2}$ in presence of a $\mathrm{Et}_{3} \mathrm{~N}$ to generate $\mathbf{L C u}(\mathrm{II})-\mathrm{OOH}$ intermediates $\left[\mathrm{Et}_{3} \mathrm{NH}\right]\left[\mathrm{Cu}\left(\mathbf{L}^{\mathbf{1}} / \mathbf{L}^{\mathbf{2}}\right)_{2}(\mathrm{OOH})\right](\mathbf{3}$ and $\mathbf{4})$ which has been

Table 3. Peroxidative catalytic oxidation of cyclohexane catalyzed by complexes $\mathbf{1}$ and $\mathbf{2}$.

\begin{tabular}{|c|c|c|c|c|c|c|c|}
\hline \multirow[t]{2}{*}{ Entry } & \multirow[t]{2}{*}{ Catalyst $^{[\mathrm{a}]}$} & \multirow[t]{2}{*}{$\frac{\mathrm{n}\left(\mathrm{NHO}_{3}\right)}{\mathrm{n}(\text { catalyst })}$} & \multirow[t]{2}{*}{$\frac{\mathrm{n} \text { (catalyst) }}{\mathrm{n}\left(\mathrm{H}_{2} \mathrm{O}_{2}\right)}$} & \multirow[t]{2}{*}{ Time (h) } & \multicolumn{3}{|c|}{ Yield $^{[b]}$ of products [\%] } \\
\hline & & & & & Cyclohexanol & Cyclohexanone & Total $^{[\mathrm{c}]}$ \\
\hline \multirow[t]{5}{*}{1} & 1 & 10 & 400 & 0 & 0.3 & 1.1 & 1.4 \\
\hline & & & & 3 & 6.22 & 4.12 & 10.34 \\
\hline & & & & 6 & 9.32 & 6.90 & 16.22 \\
\hline & & & & 12 & 13.54 & 8.77 & 22.31 \\
\hline & & & & 36 & 18.10 & 7.66 & 25.76 \\
\hline \multirow[t]{5}{*}{2} & 2 & 10 & 400 & 0 & 0.4 & 0.78 & 1.18 \\
\hline & & & & 3 & 7.98 & 3.1 & 11.08 \\
\hline & & & & 6 & 10.11 & 6.23 & 16.34 \\
\hline & & & & 12 & 14.89 & 7.98 & 22.87 \\
\hline & & & & 36 & 19.54 & 8.21 & 27.75 \\
\hline
\end{tabular}

${ }^{[a]}$ Reaction conditions: catalyst $(6.7 \mu \mathrm{mol}), \mathrm{H}_{2} \mathrm{O}_{2}(2.7 \mathrm{mmol}), \mathrm{C}_{6} \mathrm{H}_{12}(0.17 \mathrm{mmol}), \mathrm{MeCN}$ $(5 \mathrm{~mL}), 0-36 \mathrm{~h}$ reaction time.

${ }^{[b]}$ Moles of product/100 moles of cyclohexane.

${ }^{[c]}$ Cyclohexanol + cyclohexanone. 


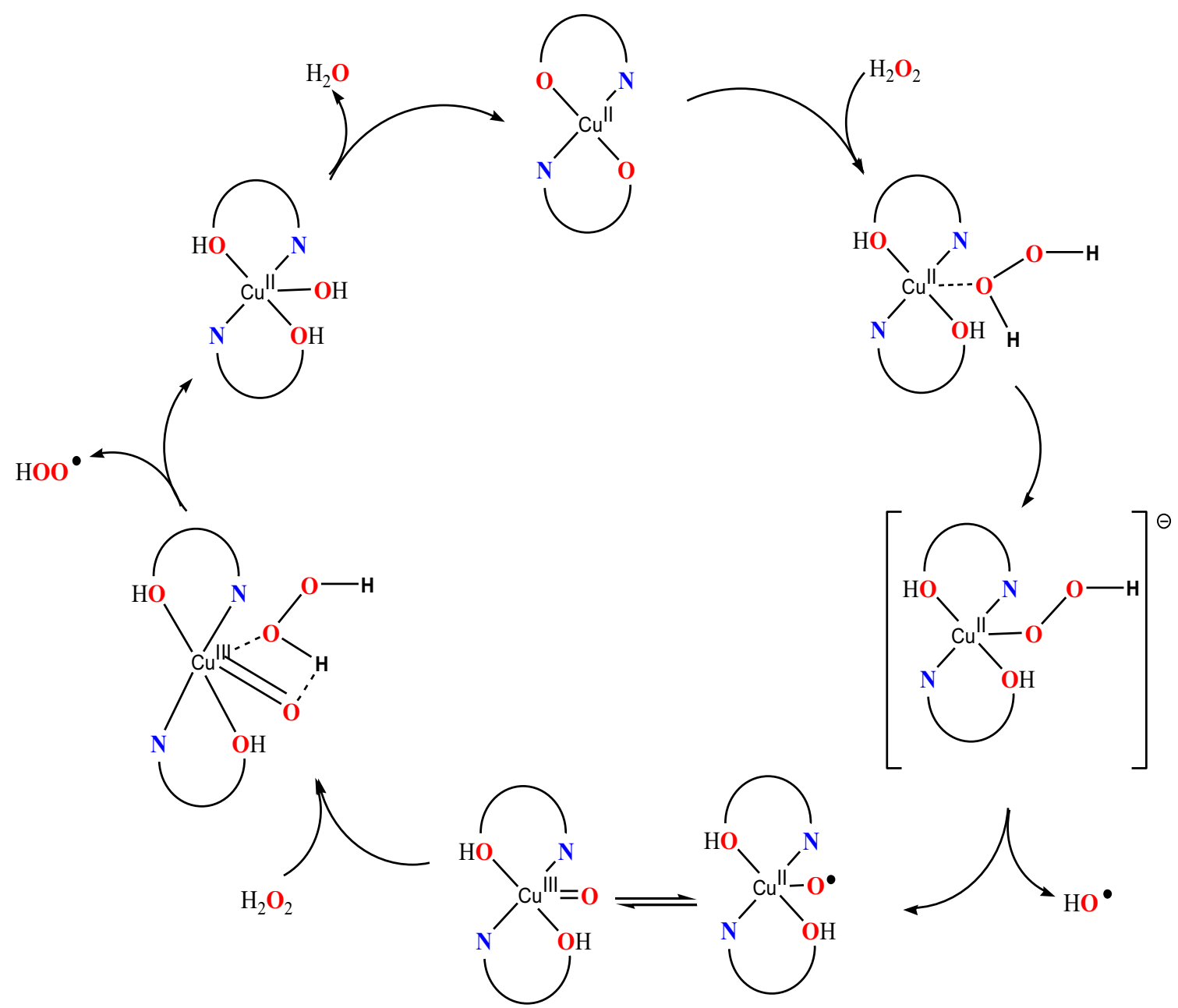

Scheme 3. A possible reaction mechanism for the formation of radical oxidant species in the catalytic cyclohexane oxidation effected by complexes 1 and 2. Please see Scheme 1 for potential (postulated) interaction between ligand thienyl moieties and the hydroperoxo group, stabilizing the hydroperoxo complex. ${ }^{9,13}$

characterized in solution. Complexes $\mathbf{1}$ and $\mathbf{2}$ have been evaluated for their catalytic ability to promote the oxidation of cyclohexane by $\mathrm{H}_{2} \mathrm{O}_{2}$. Complexes $\mathbf{1}$ and $\mathbf{2}$ were employed as catalysts in the oxidation of cyclohexane under mild reaction conditions which predominantly favour formation of cyclohexanol over cyclohexanone with complex 1 exhibiting the highest product yield (close to 20\%). These preliminary results indicate that the complexes reported herein can be employed as catalysts precursors in the mild oxidation of cyclohexane.

\section{Supplementary Information (SI)}

Spectroscopic data, ${ }^{1} \mathrm{H}$ NMR of $\mathbf{H L}^{1}$ and $\mathbf{H L}^{2}$, UV-Vis of $\mathrm{Cu}\left(\mathbf{L}^{\mathbf{1}}\right)_{2}$ and $\mathrm{Cu}\left(\mathbf{L}^{\mathbf{2}}\right)_{2}$ and ESI-MS ${ }^{+}$of $\mathbf{H L}^{\mathbf{1}}$ and $\left(\mathbf{L}^{\mathbf{1}}\right) \mathrm{Cu}(\mathrm{II})-$ $\mathrm{OOH}$ are available at http://www.ias.ac.in/chemsci. CCDC 1579065 and CCDC 1579066 contain supplementary crystallographic data for complexes $\mathrm{Cu}\left(\mathbf{L}^{\mathbf{1}}\right)_{2}(\mathbf{1})$ and $\mathrm{Cu}\left(\mathbf{L}^{\mathbf{2}}\right)_{2}(\mathbf{2})$ and have been deposited with Cambridge Crystallographic Data. These data can be obtained free of charge via http:// www.ccdc.cam.ac.uk/conts/retrieving.html, or from the Cambridge Crystallographic Data Centre, 12 Union Road, Cambridge CB2 1EZ, UK; fax: (+44) 1223-336-033; or via e-mail: deposit@ccdc.cam.ac.uk.

\section{Acknowledgements}

The authors would like to express their gratitude to the following financial entities for funding this work: CSIR and NRF (South Africa), the European Union Erasmus Mundus scheme (EUROSA), and Senate Research and Postdoctoral (UWC). Authors also would like to thank Prof. Magda Monari of the University of Bologna for correcting the disorders in the crystal structures for us.

\section{References}

1. Holm R and O'Connor M 1971 The stereochemistry of bis-chelated metal (II) complexes In Progress in Inorganic Chemistry Stephen $14^{\text {th }}$ edn. J Lippard (Ed.) (New York: John Wiley \& Sons) p. 241 
2. Garnovskiia A D, Sadimenkob A P, Sadimenkob M I and Garnovskiia D A 1998 Common and less-common coordination modes of the typical chelating and heteroaromatic ligands Coord. Chem. Rev. 17331

3. Chaudhuri P and Wieghardt K 2001 Phenoxy radical complexes In Progress in Inorganic Chemistry $50^{\text {th }}$ edn. (New York: John Wiley \& Sons) p. 151

4. Kitajima N, Whang K, Moro-oka Y, Uchida A and Sasada Y 1986 Oxidations of primary alcohols with a copper(II) complex as a possible galactose oxidase model J. Chem. Soc., Chem. Commun. 1504

5. Kasumov V T, Köksal F and Köseoğlu R 2004 Synthesis, spectroscopy and redox chemistry of bis( $n$-aryl3,5-di-tert-butylsalicylaldiminato)copper(II) complexes J. Coord. Chem. 57591

6. Iglesias A L, Aguirre G, Somanathan R and Parra-Hake M 2004 New chiral Schiff base-Cu(II) complexes as cyclopropanation catalysts Polyhedron 233051

7. Kasumov V T, Uçar I and Bulut A 2010 Synthesis, structural, spectroscopic and reactivity properties of a new N-2,3,4-trifluorophenyl-3,5-di-tertbutylsalicylaldimine ligand and its $\mathrm{Cu}(\mathrm{II})$ and $\mathrm{Pd}(\mathrm{II})$ complexes J. Fluorine Chem. 13159

8. Matsumoto N, Nonaka $\mathrm{Y}$, Kida S, Kawano S and Ueda I 1979 Synthesis and crystal structure of 1:2 molecular complexes of bis $(N$-alkyl-2-oxy1-napthylideneaminato)copper(II) and -nickel(II) with 7, 7', 8, 8'-tetracyanoquinodimethane Inorg. Chim. Acta 3727

9. Biswas S, Dutta A, Debnath M, Doloi M, Das K K and Ali M 2013 A novel thermally stable hydroperoxocopper(II) complex in a $\mathrm{Cu}\left(\mathrm{N}_{2} \mathrm{O}_{2}\right)$ chromophore of a potential $\mathrm{N}_{4} \mathrm{O}_{2}$ donor Schiff base ligand: synthesis, structure and catalytic studies Dalton Trans. 4213210

10. Ma Z, Gurbanov A V, Maharramov A M, Guseinov F I, Kopylovich M N, Zubkov F I and Pombeiro A J L 2017 Copper(II) arylhydrazone complexes as catalysts for $\mathrm{CH}$ activation in the Henry reaction in water J. Mol. Catal. A Chem. 426526

11. Fernandes R R, Lasri J, Fátima M M, da Silva C G, da Silva J A L, da Silva J J R F and Pombeiro A J L 2011 Mild alkane $\mathrm{C}-\mathrm{H}$ and $\mathrm{O}-\mathrm{H}$ oxidations catalysed by mixed-N,S copper, iron and vanadium systems Appl. Catal. A Gen. $\mathbf{4 0 2} 110$

12. Pratt R C, Lyons C T, Wasinger E C and Stack T D P 2012 Electrochemical and Spectroscopic Effects of Mixed Substituents in Bis(phenolate)-Copper(II) Galactose Oxidase Model Complexes J. Am. Chem. Soc. 134 7367

13. Biswas S, Dutta A, Dolai M, Debnath M, Jana A D and Ali M 2014 Copper(II) induced oxidative modification and complexation of a schiff base ligand: synthesis, crystal structure, catalytic oxidation of aromatic hydrocarbons and DFT calculation RSC Adv. 434248

14. Fernandes T A, André V, Kirillov A M and Kirillova M V 2017 Mild homogeneous oxidation and hydrocarboxylation of cycloalkanes catalyzed by novel dicopper(II) aminoalcohol-driven cores J. Mol. Catal. A Chem. 426 357

15. Hatcher L and Karlin K 2004 Oxidant types in copperdioxygen chemistry: the ligand coordination defines the
$\mathrm{Cu}_{\mathrm{n}}-\mathrm{O}_{2}$ structure and subsequent reactivity J. Biol. Inorg. Chem. 9669

16. Lucas H R, Li L, Narducci Sarjeant A A, Vance M A, Solomon E I and Karlin K D 2009 Toluene and ethylbenzene aliphatic $\mathrm{C}-\mathrm{H}$ bond oxidations initiated by a dicopper(II)- $\mu$-1,2-peroxo complex J. Am. Chem. Soc. 1313230

17. Kirillov A M, Kirillova M V and Pombeiro A J L 2012 Multicopper complexes and coordination polymers for mild oxidative functionalization of alkanes Coord. Chem. Rev. 2562741

18. (a) Kirillov A M, Kopylovich M N, Kirillova M V, Haukka M, da Silva M F C G and Pombeiro A J L 2005 Multinuclear Copper Triethanolamine Complexes as Selective Catalysts for the Peroxidative Oxidation of Alkanes under Mild Conditions Angew. Chemie Int. Ed. 44 4345; (b) Kirillov A M, Kopylovich M N, Kirillova M V, Karabach E Y, Haukka M, da Silva M F C G and Pombeiro A J L 2006 Mild Peroxidative Oxidation of Cyclohexane Catalyzed by Mono-, Di-, Tri-, Tetra- and Polynuclear Copper Triethanolamine Complexes $A d v$. Synth. Catal. 348159

19. Karabach Y Y, Kirillov A M, Haukka M, Kopylovich M N and Pombeiro A J L 2008 Copper(II) coordination polymers derived from triethanolamine and pyromellitic acid for bioinspired mild peroxidative oxidation of cyclohexane J. Inorg. Biochem. 1021190

20. Figiel P J, Kirillov A M, Karabach Y Y, Kopylovich M N and Pombeiro A J L 2009 Mild aerobic oxidation of benzyl alcohols to benzaldehydes in water catalyzed by aqua-soluble multicopper(II) triethanolaminate compounds J. Mol. Catal. A Chem. 305178

21. Saint-Aman E, Me'nage S, Pierre J L, Defrancq E and Gellon G 1998 A functional model of galactose oxidase: catalytic oxidation of primary alcohols with a one-electron oxidized copper(II) complex New J. Chem. 22393

22. Gamez P, Arends I W C E, Reedijk J and Sheldon R A 2003 Copper(II)-catalysed aerobic oxidation of primary alcohols to aldehydes Chem. Commun. 2414

23. Breza M and Biskupič S $2006 \quad N$ Salicylideneaminoacidato copper(II) complexes as galactose oxidase model compounds J. Mol. Struct.: THEOCHEM 760141

24. Velusamy S, Srinivasan A and Punniyamurthy T 2006 Copper(II) catalyzed selective oxidation of primary alcohols to aldehydes with atmospheric oxygen Tetrahedron Lett. 47923

25. Kasumov V T, Bulut A, Köksal F, Aslanoğlu M, Uçar I, Kazak C 2006 Synthesis, structure, spectroscopic and redox properties of copper(II)- $N-3,5-\mathrm{Bu}_{2}^{t}$ phenylsalicylaldinine complexes: Crystal and molecular structure of bis $\left(\mathrm{N}-3,5-\mathrm{Bu}_{2}^{t}\right.$ phenylsalicylaldininato)copper(II) Polyhedron $\mathbf{2 5}$ 1133

26. Cowley R E, Cirera J, Qayyum M F, Rokhsana D, Hedman B, Hodgson K O, Dooley D M and Solomon E I 2016 Structure of the Reduced Copper Active Site in Preprocessed Galactose Oxidase: Ligand Tuning for One-Electron $\mathrm{O}_{2}$ Activation in Cofactor Biogenesis $J$. Am. Chem. Soc. 13813219 
27. Shepard E M and Dooley D M 2015 Inhibition and Oxygen Activation in Copper Amine Oxidases Acc. Chem. Res. 481218

28. Miller S M and Klinman J P 1983 Magnitude of intrinsic isotope effects in the dopamine beta-monooxygenase reaction Biochemistry 223091

29. Miller S M and Klinman J P 1985 Secondary isotope effects and structure-reactivity correlations in the dopamine beta-monooxygenase reaction: evidence for a chemical mechanism Biochemistry 242114

30. Tian G, Berry J A and Klinman J P 1994 Oxygen18 kinetic isotope effects in the dopamine betamonooxygenase reaction: evidence for a new chemical mechanism in non-heme metallomonooxygenases Biochemistry 33226

31. Francisco W A, Merkler D J, Blackburn N J and Klinman J P 1998 Kinetic mechanism and intrinsic isotope effects for the peptidylglycine alpha-amidating enzyme reaction Biochemistry 378244

32. Chen P, Fujisawa K and Solomon E I 2000 Spectroscopic and Theoretical Studies of Mononuclear Copper(II) Alkyl- and Hydroperoxo Complexes: Electronic Structure Contributions to Reactivity J. Am. Chem. Soc. 122 10177

33. Kodera M, Kita T, Miura I, Nakayama N, Kawata T, Kano K and Hirota S 2001 Hydroperoxo-Copper(II) Complex Stabilized by $\mathrm{N}_{3} \mathrm{~S}$-Type Ligand Having a Phenyl Thioether J. Am. Chem. Soc. 1237715

34. (a) Wada A, Harata M, Hasegawa K, Jitsukawa K, Masuda H, Mukai M, Kitagawa $\mathrm{T}$ and Einaga $\mathrm{H}$ 1998 Structure and spectroscopic characterization of a mononuclear hydroperoxo-copper(II) complex with tripodal pyridylamine ligands Angew. Chem., Int. Ed. 37 798; (b) Fujii T, Naito A, Yamaguchi S, Wada A, Funahashi Y, Jitsukawa K, Nagatomo S, Kitagawa T and Masuda H 2003 Construction of a square-planar hydroperoxo-copper(II) complex inducing a higher catalytic reactivity Chem. Commun. 422700

35. Evans J P, Ahn K and Klinman J P 2003 Evidence That Dioxygen and Substrate Activation Are Tightly Coupled in Dopamine $\beta$-Monooxygenase J. Biol. Chem. 278 49691

36. (a) Motswainyana W M, Ojwach S O, Onani M O, Iwuoha E I and Darkwa J 2011 Novel hemi-labile pyridyl-imine palladium complexes: Synthesis, molecular structures and reactions with ethylene Polyhedron 30 2574; (b) Motswainyana W M, Onani M O, Ojwach S O and Omondi B 2012 New imino-pyridyl nickel(II) complexes: Synthesis, molecular structures and application as Heck coupling catalysts Inorganica. Chim. Acta 391 93; (c) Motswainyana W M, Onani M O and Madiehe A 2012 Bis(ferrocenylimine)palladium(II) and platinum(II) complexes: Synthesis, molecular structures and evaluation as antitumor agents Polyhedron 4144

37. Kundu S, Biswas S, Mondal AS, Roy P and Mondal T K 2015 Template synthesis of square-planar Ni(II) complexes with new thiophene appended Schiff base ligands: Characterization, X-ray structure and DFT calculation $J$. Mol. Struct. 110027

38. Kundu S, Pramanik A K, Mondal A S and Mondal T K $2016 \mathrm{Ni}$ (II) and Pd(II) complexes with new N,O donor thiophene appended Schiff base ligand: Synthesis, electrochemistry, X-ray structure and DFT calculation $J$. Mol. Struct. 11161

39. Elantabli F M, Radebe M P, Motswainyana W M, Owaga B O, El-Medani S M, Ekengard E, Haukka M, Nordlander E and Onani M O 2017 Thiophene based imino-pyridyl palladium(II) complexes: Synthesis, molecular structures and Heck coupling reactions $J$. Organomet. Chem. 84340

40. Cai Y P, Su C Y, Xu A W, Kang B S, Tong Y X, Liu H Q and Jie S 2001 Syntheses and characterization of copper(II) complexes of bis(acetylacetone)trimethylenediimine Polyhedron 20 657

41. Fujii T, Yamaguchi S, Funahashi Y, Ozawa T, Tosha T, Kitagawa T and Masuda H 2006 Mononuclear copper(II)-hydroperoxo complex derived from reaction of copper(I) complex with dioxygen as a model of D $\beta \mathrm{M}$ and PHM Chem. Commun. 1104428

42. Mizuno M, Honda K, Cho J, Furutachi H, Tosha T, Matsumoto T, Fujinami S, Kitagawa T and Suzuki M 2006 A Mononuclear Alkylperoxocopper(II) Complex as a Reaction Intermediate in the Oxidation of the Methyl Group of the Supporting Ligand Angew. Chemie Int. Edit. $\mathbf{4 5} 6911$

43. Tano T, Ertem M Z, Yamaguchi S, Kunishita A, Sugimoto H, Fujieda N, Ogura T, Cramer C J and Itoh S 2011 Reactivity of copper(II)-alkylperoxo complexes Dalton Trans. 4010326

44. Kirillova M V, Kuznetsov M L, Kozlov Y N, Shul'pina L S, Kitaygorodskiy A K, Pombeiro A J L and Shul'pin G B 2011 Participation of Oligovanadates in Alkane Oxidation with $\mathrm{H}_{2} \mathrm{O}_{2}$ Catalyzed by Vanadate Anion in Acidified Acetonitrile: Kinetic and DFT Studies ACS Catal. 11511

45. (a) Bruker 2006 SAINT Version 7.60a (Madison, Wisconsin, USA: Bruker AXS Inc.); (b) Sheldrick G M 1997 SHELXS-97, SHELXL-2014 and SADABS version 2.05, University of Göttingen, Germany; (c) Barbour L J 2001 X-Seed-A software tool for supramolecular crystallography J. Supramol. Chem. 1 189; (d) Atwood J L and Barbour L J 2003 Molecular graphics: from science to art Cryst. Growth Des. 3 3; (e) http://www.povray.org (Accessed on: 2 November 2017)

46. (a) Atzori M, Pop F, Cauchy T, Mercuri M L and Avarvari N 2014 Thiophene- benzoquinone: synthesis, crystal structure and preliminary coordination of anilate ligands Org. Biomol. Chem. 12 8752; (b) Adhikary J, Chakraborty A, Dasgupta S, Chattopadhyay S K, Kruszynski R, Trzesowska-Kruszynska A, Stepanović S, Gruden- Pavlović M, Swart M and Das D 2016 Unique mononuclear MnII complexes of an end-off compartment Schiff base ligand: experimental and theoretical studies on their bio-relevant catalytic promiscuity Dalton Trans. 45 12409; (c) Rani C V, Mitu L, Chakkaravarthi G and Rajagopal G 2017 Bis3,5-di-tert-butyl-N-[(4methylamino)phenyl]salicylaldiminatocobalt(II) $\mathrm{IUCr}$ Data 2 x 170525

47. Samanta S, Ray S, Joardar S and Dutta S 2015 Synthesis and characterization of mononuclear copper (II) complexes of pyridine 2-carboxamide: Their application as catalyst in peroxidative oxidation agents and antimicrobial agents J. Chem. Sci. 1271451 